\title{
VARIABILITY OF DISSOLVED INORGANIC RADIOCARBON AT A SURFACE SITE IN THE NORTHEAST PACIFIC OCEAN
}

\author{
Ellen R M Druffel ${ }^{1,2} \bullet$ Steven Beaupré $^{\bullet}$ Sheila Griffin ${ }^{1}$ Jeomshik Hwang ${ }^{3}$
}

ABSTRACT. We report radiocarbon measurements of dissolved inorganic carbon (DIC) in surface water samples collected daily during 12 cruises to Station $\mathrm{M}$ in the northeast Pacific off central California. Individual surface $\Delta^{14} \mathrm{C}$ values ranged from $22 \%$ to $70 \%$ over $10 \mathrm{yr}$. Variability of average cruise values is highest during winter likely due to increased mixing. A general decrease of $\Delta{ }^{14} \mathrm{C}$ values was observed at a rate of about 3\%o per year between 1994 and 2004, about half of that in atmospheric $\mathrm{CO}_{2}$ during this period (Levin and Kromer 2004). The $\Delta^{14} \mathrm{C}$ results ranged from 2-18\%o during individual cruises and were often significantly larger than the total uncertainty for individual measurements $( \pm 3.9 \%)$. This indicates that a single $\Delta^{14} \mathrm{C}$ result from a surface site is not sufficient to capture the true variability of $\Delta^{14} \mathrm{C}$ in the surface ocean.

\section{INTRODUCTION}

Radiocarbon levels in dissolved inorganic carbon (DIC) of non-polar surface ocean waters were approximately 4-7\% lower than $\mathrm{CO}_{2}$ in the pre-bomb atmosphere, causing a reservoir age of $\sim 300$ $600{ }^{14} \mathrm{C}$ yr in mixed layer DIC. A minor reason for this depletion is the high impedance for $\mathrm{CO}_{2}$ exchange between air and sea. That is, DIC in the mixed layer $(0-100 \mathrm{~m}$ depth) would exchange with the atmosphere in about $10 \mathrm{yr}\left(2 \mathrm{moles} / \mathrm{m}^{3} \bullet 100 \mathrm{~m} / 20 \mathrm{moles} \mathrm{CO}_{2} / \mathrm{m}^{2} / \mathrm{yr}\right)$. The major reason for the reservoir age of the surface ocean DIC is mixing with subsurface waters that are ${ }^{14} \mathrm{C}$-depleted due to isolation from the atmosphere and subsequent radioactive decay. Therefore, surface waters exchange with subsurface ${ }^{14} \mathrm{C}$-depleted water faster than with the atmosphere, creating ${ }^{14} \mathrm{C}$-depleted surface waters with respect to the contemporaneous atmosphere and hence a reservoir age.

Temporal variability of the reservoir age at a given location in the surface ocean has been studied using seasonal and monthly coral skeletons (Brown et al. 1993; Guilderson et al. 2000) and daily surface water samples collected at sea (McDuffee and Druffel 2007; Druffel and Griffin 2008). A reason to know the temporal variability of the reservoir age is to constrain the uncertainty in the initial ${ }^{14} \mathrm{C}$ signature of surface-derived carbon when calculating the residence times of carbon pools in the ocean. For example, ${ }^{14} \mathrm{C}$ analyses of pairs of benthic-planktonic foraminifera within the sediment column allow estimates of the ventilation age of the deep ocean, which would have higher uncertainties if the ${ }^{14} \mathrm{C}$ measurement of planktonic (surface) forams had a larger range of values. Daily measurements of surface seawater in the Sargasso Sea during June 2000 indicated a change in water mass that was coincident with an increase in variability of $\Delta{ }^{14} \mathrm{C}$ values $(\mathrm{McDuffee}$ and Druffel 2007) halfway through the cruise. Druffel and Griffin (2008) showed that daily sampling at 3 locations (north central Pacific, Sargasso Sea, and Southern Ocean) over the course of 2-4 week periods revealed surface $\Delta^{14} \mathrm{C}$ values that varied by $11-30 \%$, more than the total uncertainty of the measurement $(7.8 \%, 2 \sigma)$ during all 6 cruises. Changes in the upper water mass were observed during most of these cruises, as determined by temperature-salinity relationships.

We report daily surface DIC $\Delta^{14} \mathrm{C}$ values obtained for 12 cruises to Station M (Stn M), a high-productivity site located $220 \mathrm{~km}$ west of Point Conception, California. We report that the ranges of $\Delta^{14} \mathrm{C}$ measurements obtained for the cruises was $2-18 \%$, and for some of the cruises was greater than the total uncertainty $(7.8 \%, 2 \sigma)$ of the measurements. In addition, we report that storage of DIC samples for up to $3 \mathrm{yr}$ causes minimal sacrifice in precision of the ${ }^{14} \mathrm{C}$ measurements.

\footnotetext{
${ }^{1}$ Department of Earth System Science, University of California, Irvine, California 92697-3100, USA.

${ }^{2}$ Corresponding author. Email: edruffel@uci.edu.

${ }^{3}$ School of Environmental Science and Engineering, POSTECH, Pohang 790-784, Korea.
}

C 2010 by the Arizona Board of Regents on behalf of the University of Arizona Proceedings of the 20th International Radiocarbon Conference, edited by A J T Jull RADIOCARBON, Vol 52, Nr 2-3, 2010, p 1150-1157 


\section{METHODS}

Daily surface water samples were collected from a single site $\left(34^{\circ} 50^{\prime} \mathrm{N}, 123^{\circ} 00^{\prime} \mathrm{W}\right)$ in the northeastern Pacific during 12 Pulse ("P" hereafter) cruises between 1994 and 2004. The dates and number of days spent on Stn M during each cruise are listed in Table 1.

Table 1 Average surface data from 12 Pulse cruises to Stn M.

\begin{tabular}{|c|c|c|c|c|c|c|c|c|c|c|c|}
\hline $\begin{array}{l}\text { Pulse- } \\
\text { cruise } \\
\mathrm{nr}\end{array}$ & $\begin{array}{l}\text { First day } \\
\text { of cruise }\end{array}$ & $n$ & $\begin{array}{l}\text { Average } \\
\Delta^{14} \mathrm{C} \\
\% \text { o }\end{array}$ & $\begin{array}{l}\mathrm{sd} \\
\% 0\end{array}$ & $\begin{array}{l}\text { Range } \\
\Delta^{14} \mathrm{C} \\
\text { values } \\
\% 0\end{array}$ & $\begin{array}{l}\text { Average } \\
\delta^{13} \mathrm{C} \\
\% \\
\%\end{array}$ & $\begin{array}{l}\mathrm{sd} \\
\% 0\end{array}$ & $\begin{array}{l}\text { Average } \\
\mathrm{SST} \\
{ }^{\circ} \mathrm{C}\end{array}$ & $\begin{array}{l}\text { Average } \\
\text { salinity } \\
\text { psu }\end{array}$ & $\begin{array}{l}\text { Average } \\
\text { alkalinity } \\
\mu \mathrm{eq} / \mathrm{kg}\end{array}$ & $\begin{array}{l}\text { Average } \\
\mathrm{TCO}_{2} \\
\mu \mathrm{mol} / \mathrm{kg}\end{array}$ \\
\hline 22 & 9/16/94 & 6 & 52.0 & 6.3 & 18.3 & 1.67 & 0.06 & 15.5 & 33.29 & 2229 & 1979 \\
\hline 25 & $4 / 23 / 95$ & 5 & 59.4 & 4.4 & 10.2 & 1.60 & 0.09 & 12.2 & 32.56 & 2202 & 1975 \\
\hline 26 & $6 / 3 / 95$ & 4 & 61.3 & 2.8 & 6.5 & 1.57 & 0.04 & 11.8 & 32.83 & 2206 & 1989 \\
\hline 29 & $1 / 28 / 96$ & 8 & 52.6 & 6.6 & 18.3 & $1.39^{\mathrm{a}}$ & 0.16 & 14.1 & 33.28 & 2286 & 1999 \\
\hline 30 & $5 / 31 / 96$ & 4 & 65.3 & 4.4 & 4.7 & 1.57 & 0.02 & 16.8 & 33.19 & 2314 & 1988 \\
\hline 31 & $10 / 8 / 96$ & 5 & 42.8 & 4.5 & 11.0 & 1.42 & 0.04 & 16.6 & 33.46 & 2239 & 1966 \\
\hline 37 & $6 / 16 / 01$ & 2 & 40.1 & 4.2 & 5.9 & 1.43 & 0.03 & 15.2 & & & \\
\hline 38 & $10 / 25 / 01$ & 3 & 30.4 & 7.6 & 15.3 & & & & & & \\
\hline 39 & $2 / 23 / 02$ & 3 & 40.1 & 9.0 & 17.8 & 1.71 & 0.06 & 12.9 & & & \\
\hline 40 & $6 / 10 / 02$ & 3 & 27.0 & 1.2 & 2.3 & & & 15.0 & & & \\
\hline 41 & $9 / 5 / 02$ & 2 & 30.8 & 1.1 & 1.6 & 1.55 & 0.07 & 17.0 & & & \\
\hline 45 & $10 / 27 / 04$ & 4 & 32.1 & 1.0 & 2.0 & 1.68 & 0.01 & 17.5 & & & \\
\hline
\end{tabular}

${ }^{a}$ Average value does not include anomalously low daily value of $0.4 \%$.

Seawater samples were collected from $0-0.5 \mathrm{~m}$ depth using a plastic bucket as described previously (Druffel and Griffin 2008). Sea surface temperature (SST) measurements were made using an ethanol thermometer $\left( \pm 0.2^{\circ} \mathrm{C}\right)$. Samples were collected between 1100 and $1400 \mathrm{hr}$ local time. Seawater samples for isotopic, $\mathrm{TCO}_{2}$, and alkalinity analyses were poisoned with saturated $\mathrm{HgCl}_{2}$ solution following DOE protocol (DOE 1994). The $\mathrm{TCO}_{2}$, alkalinity, and salinity measurements are available only for the first 6 cruises.

Water samples were processed and measured for DIC $\Delta^{14} \mathrm{C}$ using accelerator mass spectrometry (AMS) techniques (McNichol et al. 1994; Southon et al. 2004). ${ }^{14} \mathrm{C}$ measurements are reported as $\Delta^{14} \mathrm{C}$ in per mil (Stuiver and Polach 1977) with a total uncertainty of $\pm 3.9 \%$ (see below). Stable carbon isotope measurements $\left(\delta^{13} \mathrm{C}\right)$ were performed at the University of California, Irvine (UCI) on splits of $\mathrm{CO}_{2}$ from the processed ${ }^{14} \mathrm{C}$ samples using a Finnigan Delta Plus isotope ratio mass spectrometer (IRMS) with a total uncertainty of $\pm 0.05 \%$.

A standard water sample was collected during the P-26 cruise on 4 June 1995 from a depth of $450 \mathrm{~m}$ and stored in 22 one-L glass bottles. The samples were processed and analyzed for ${ }^{14} \mathrm{C}$ up to $8 \mathrm{yr}$ after collection. ${ }^{14} \mathrm{C}$ results of 17 samples processed between November 1996 and April 2003 averaged $-100.9 \pm 4.4 \%$. There was a slight increase in the scatter of the $\Delta^{14} \mathrm{C}$ values for seawater samples that were processed more than $5 \mathrm{yr}$ after collection (1996-1998, average $-100.6 \pm 3.9 \%, n=$ $10 ; 2000-2003,-101.4 \pm 4.8 \%, n=7$, respectively). These results agree with McNichol et al. (1994) who reported that storage of seawater samples for up to $2.5 \mathrm{yr}$ did not jeopardize isotopic or concentration measurements of DIC. The surface samples reported here were processed within $1 \mathrm{yr}$ of collection and have been assigned a total uncertainty of $\pm 3.9 \%$.

Alkalinity and $\mathrm{TCO}_{2}$ measurements were obtained by closed-vessel titration of large-volume $(\sim 100 \mathrm{~mL})$ samples using an automated titration system (Bradshaw et al. 1981; Brewer et al. 1986) 
in the laboratory of C Goyet or D McCorkle at Woods Hole Oceanographic Institution. Measurements were determined using a nonlinear curve fitting approach (DOE 1994) and standardized using certified reference materials obtained from A Dickson at Scripps Institution of Oceanography.

\section{RESULTS AND DISCUSSION}

Individual $\Delta^{14} \mathrm{C}$ measurements of daily samples collected from the 12 cruises ranged from a high of $70 \%$ (May 1996, day 4) to a low of 22\% (Oct 2001, day 3) (Figure 1a). Average $\Delta^{14} \mathrm{C}$ values for each cruise ranged from $65.3 \pm 4.4 \%$ (May 1996) to $27.0 \pm 1.2 \%$ (Jun 2002) (Table 1) and generally declined with time as bomb ${ }^{14} \mathrm{C}$ decreased in the atmosphere and penetrated into the ocean's interior (Figure 1b). Variability (standard deviation) of the average $\Delta^{14} \mathrm{C}$ values was higher during the 2 winter cruises (6.6\% for Jan 1996 and 9.0\%o for Feb 2002) compared to those during other seasons (from
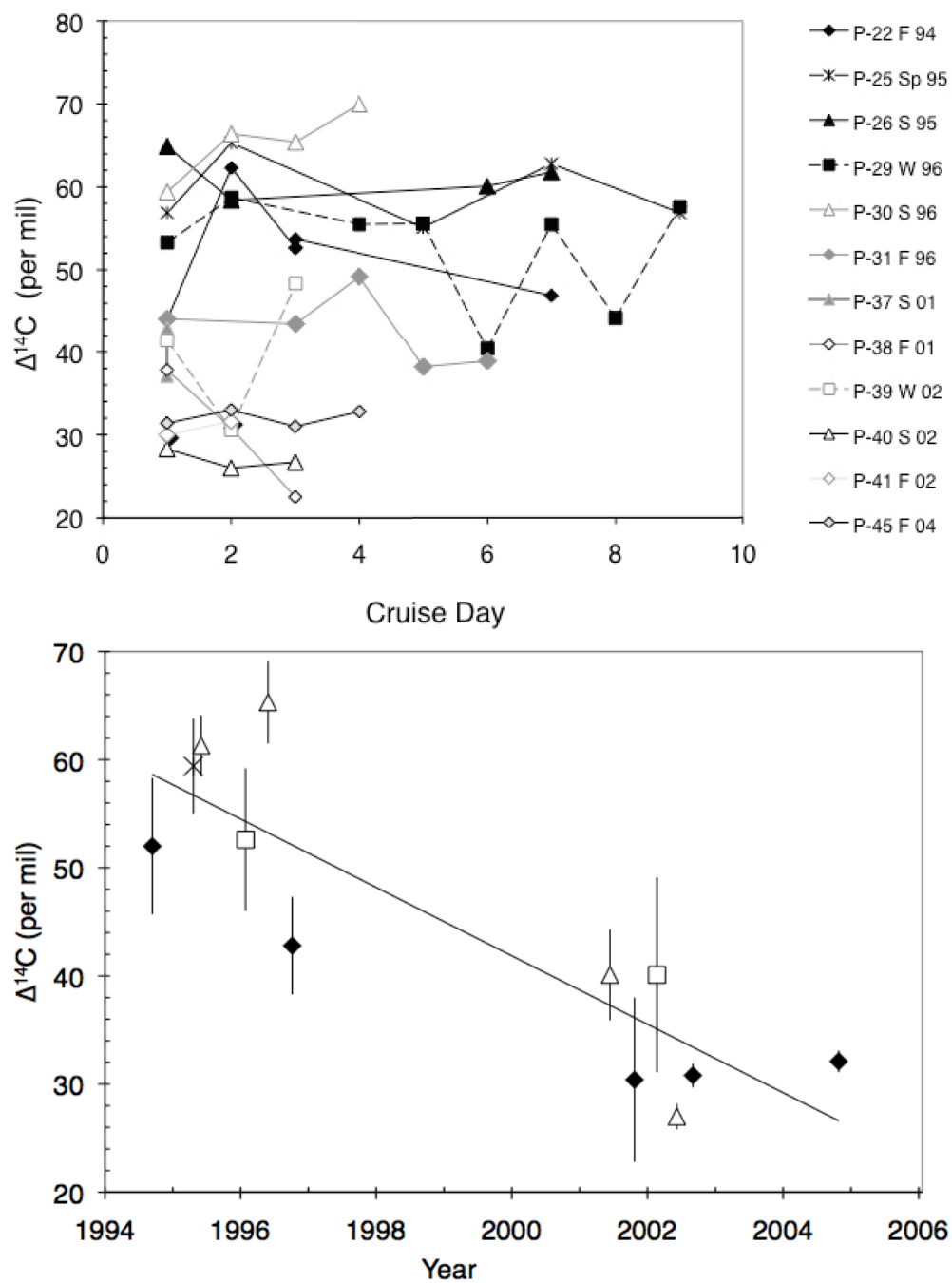

Figure 1 a) Time series of daily surface DIC $\Delta{ }^{14} \mathrm{C}$ values versus time by cruise day, and b) average of daily surface DIC $\Delta^{14} \mathrm{C}$ values for summer (triangles), spring (asterisk) and fall (diamonds) and winter (squares) cruises versus calendar date, where (tic marks indicate 1 January). 
$1.0 \%$ to $7.6 \%$ for Oct 2004 and Oct 2001, respectively, Table 1). Higher variability in the surface ocean is expected during periods of increased mixing with low $\Delta^{14} \mathrm{C}$ subsurface waters, which occurs during wintertime. Seasonal trends are suggested for years with multiple cruises, and in general, summer $\Delta^{14} \mathrm{C}$ values are higher than other seasons $(1995,1996,2001)$ (Figure 1b). This is in agreement with seasonal trends observed in $\Delta^{14} \mathrm{C}$ values from $25 \mathrm{~m}$ at $\mathrm{Stn} \mathrm{M}$ from 1992 to 1995 (Masiello et al. 1998). The exception is 2002, which has a lower average summer $\Delta^{14} \mathrm{C}$ value (average $27.0 \pm$ $1.2 \% \mathrm{sd})$ than those for the winter or fall of that year $(40.1 \pm 9.1 \%$, $30.8 \pm 1.1 \%$, respectively).

Stable carbon isotope results $\left(\delta^{13} \mathrm{C}\right)$ were within the narrow range of $1.1-1.8 \%$, with the exception of 1 low value $(0.4 \%$, winter 1996$)$ (Figure 2$)$. Variability of the $\delta^{13} \mathrm{C}$ results was $0.01-0.16 \%$ (Table 1), within $\sim 3 \sigma$ of our measurement uncertainty $\left( \pm 0.05 \%\right.$ ). Similar to ${ }^{14} \mathrm{C}, \delta^{13} \mathrm{C}$ values are expected to be lower and more variable during periods of increased mixing because $\delta^{13} \mathrm{C}$ values decrease with depth in the water column due to the presence of respired $\mathrm{CO}_{2}$. For example, (Masiello et al. 1998) reported that $\delta^{13} \mathrm{C}$ values at $450 \mathrm{~m}$ depth were $2-2.5 \%$ lower than those in surface waters at Stn M.

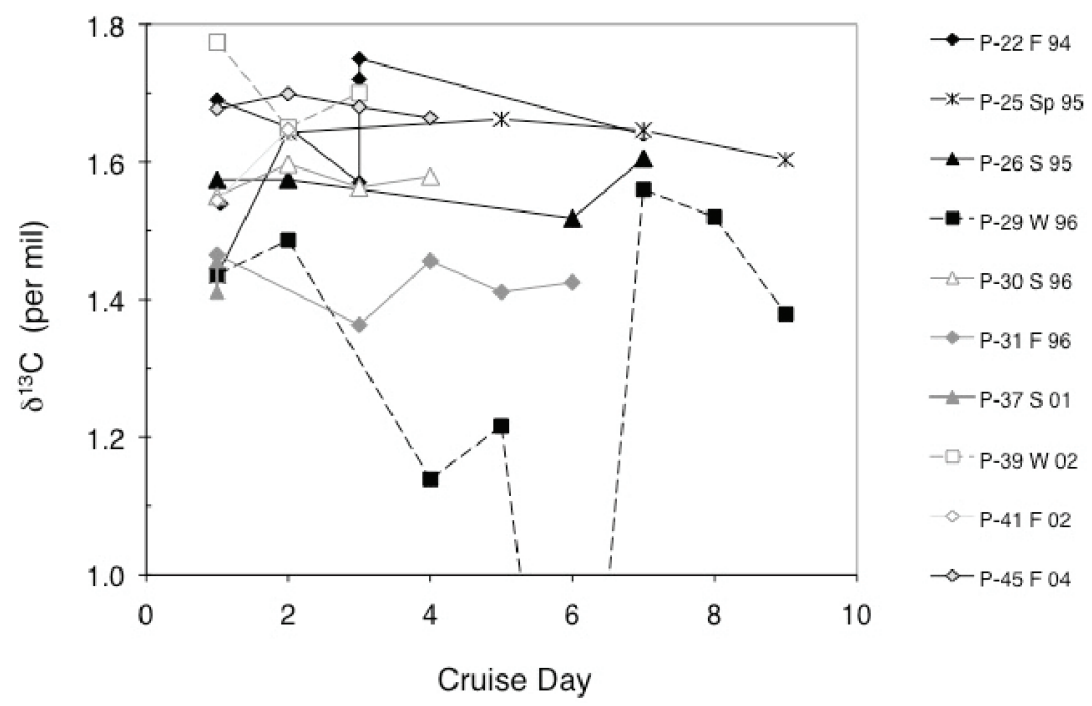

Figure 2 Time series of daily surface DIC $\delta^{13} \mathrm{C}$ values versus cruise day

The SST values ranged from $12-18{ }^{\circ} \mathrm{C}$ and the standard deviation of the average values for each cruise was $<1{ }^{\circ} \mathrm{C}$, except during June 2002 when it was higher $\left(1.8^{\circ} \mathrm{C}\right)$ (Figure 3a). Temperatures were lowest during April and June 1995 (averages of $12.2^{\circ}$ and $11.8^{\circ} \mathrm{C}$, respectively). There was no apparent correlation between the isotope data and SST values from individual cruises or the collective data sets.

Salinity, alkalinity, and $\mathrm{TCO}_{2}$ data are available for only the first 6 cruises (1994-1996). Average salinity values ranged from $32.56 \%$ to $33.46 \%$, with lower average values obtained for April and June 1995 than for the other cruises (Figure 3b). Similarly, the same 2 cruises had the lowest average SST values (Figure 3a). Average alkalinity measurements (Figure 3c) were also lowest during April and June of 1995 (averages of 2202 and $2206 \mu \mathrm{eq} / \mathrm{kg}$, respectively), intermediate during September 1994 and October 1996 (2229 and $2239 \mu \mathrm{eq} / \mathrm{kg}$, respectively), and highest during January and June 1996 (2286 and $2314 \mu \mathrm{eq} / \mathrm{kg}$, respectively). The average $\mathrm{TCO}_{2}$ measurements were highest during January $1996(1999 \mu \mathrm{mol} / \mathrm{kg})$ and lower $(1966-1989 \mu \mathrm{mol} / \mathrm{kg})$ during the other 5 cruises. 

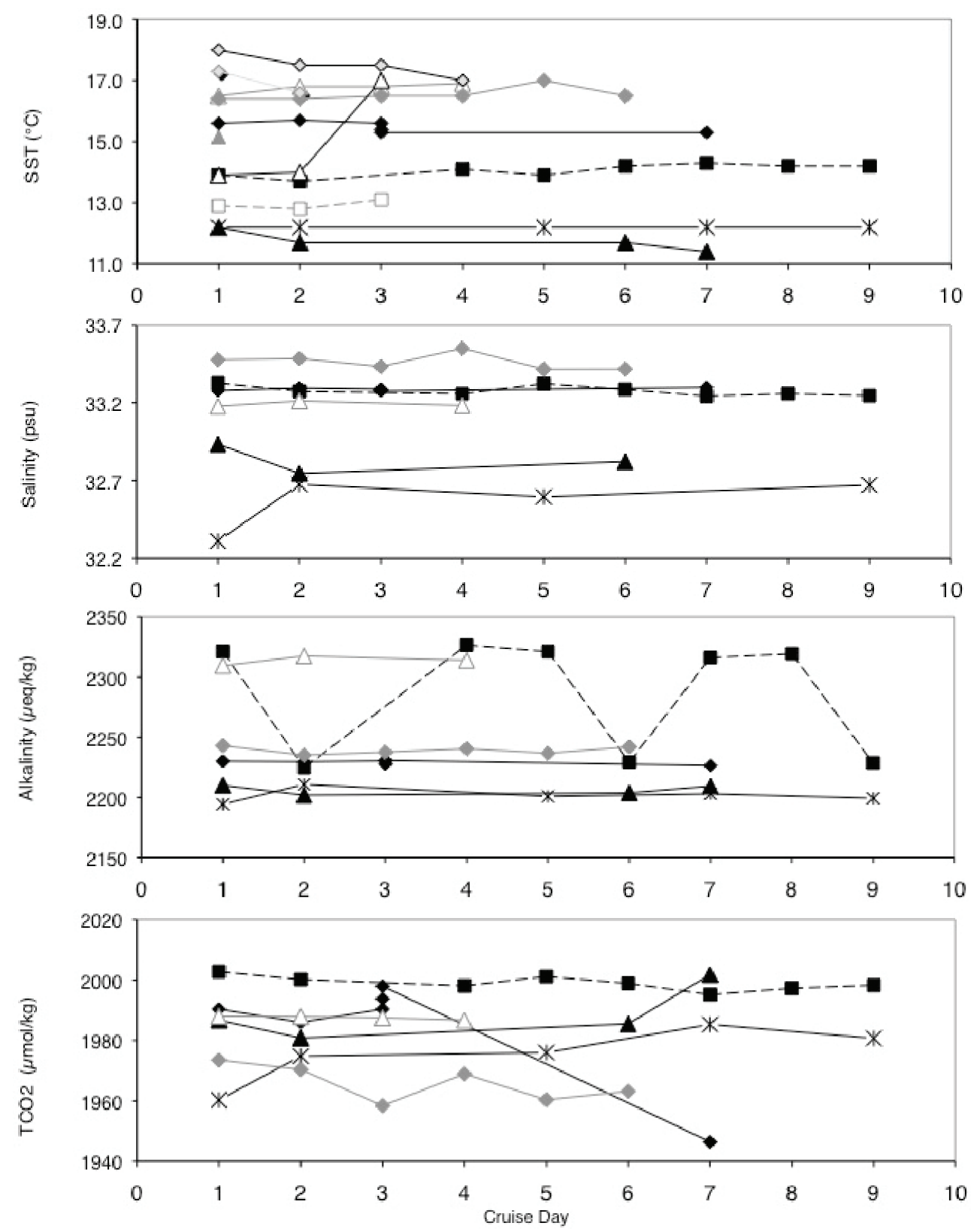

Figure 3 Time series of daily a) SST, b) salinity, c) alkalinity, and d) $\mathrm{TCO}_{2}$ values for surface water samples taken daily during Pulse cruises to Station M. Points are the same as in Figures 1a and 2.

Correlations were observed between some of the daily isotopic and chemical data sets. The $\Delta^{14} \mathrm{C}$ values were detrended to eliminate the long-term decline of values over the decade of observations $(\sim 3 \% / \mathrm{yr})$. There is a significant correlation between $\delta^{13} \mathrm{C}$ and detrended $\Delta^{14} \mathrm{C}$ values $(p=0.05, n=$ 44), though when the anomalously low $\delta^{13} \mathrm{C}$ value (0.4\%o) obtained during January 1996 is not included, the correlation is no longer significant. 
Daily salinity and $\Delta^{14} \mathrm{C}$ values were anti-correlated $(p=0.05, n=30)$ for the period $1994-1996$. This agrees with the observation that salinity increases with depth at this site year-round, and $\Delta^{14} \mathrm{C}$ values decrease with depth due to mixing with low $\Delta^{14} \mathrm{C}$ waters from below the thermocline (Masiello et al. 1998). Alkalinity values are also significantly correlated with salinity $(p=0.02, n=30)$ and $\mathrm{TCO}_{2}$ $(p=0.05, n=33)$ measurements. Again, alkalinity and $\mathrm{TCO}_{2}$ values increase with depth in the upper water column. These correlations suggest that mixing between the surface and subsurface waters is important for maintaining the chemical and isotopic compositions of seawater at Stn M. Masiello et al. (1998) used a simple 2-box model to show that observed changes in wind-speed (5.5-12 m/s) are related to the DIC $\Delta^{14} \mathrm{C}$ variability in the upper $25 \mathrm{~m}$ at Stn M from 1991-1994. A similar relationship was not found with the DIC $\Delta{ }^{14} \mathrm{C}$ values at $85 \mathrm{~m}$ depth, because the depth of the California Current varies between 30 and $150 \mathrm{~m}$ seasonally (Masiello et al. 1998).

A major climatological phenomenon in the Pacific is El Niño-Southern Oscillation (ENSO), which is generally associated with suppressed upwelling off the California coast. When our cruise-averaged $\delta^{13} \mathrm{C}$ values are plotted with the corresponding values for the monthly Multivariate ENSO Index (MEI) (Wolter 2007), we observe a significant correlation ( $p=0.1)$, suggesting that $\delta^{13} \mathrm{C}$ is an upwelling indicator at Stn M. We did not observe significant correlations between detrended average $\Delta^{14} \mathrm{C}$ values and the MEI, nor were there significant correlations observed between the chemical measurements $\left(\mathrm{TCO}_{2}\right.$, alkalinity, and salinity) and the MEI. We note that the chemical and isotopic data are sparse, and may not provide a fair test of relationships with climate if they exist.

To further examine the cause of the $\Delta^{14} \mathrm{C}$ variability in the surface waters, we compare the surface $\Delta \Delta^{14} \mathrm{C}$ results reported here with $\Delta{ }^{14} \mathrm{C}$ measurements from water collected at $25 \mathrm{~m}$ depth on 7 of our cruises, none of which were during winter months (Masiello et al. 1998; Beaupré and Druffel 2009). A plot of the $25 \mathrm{~m} \Delta{ }^{14} \mathrm{C}$ vs. surface $\Delta^{14} \mathrm{C}$ of samples taken on the same day reveals a significant correlation $(r=0.93, p=0.002)$ for the least-squares fit (black line, Figure 4$)$; the slope $(0.690 \pm 0.120)$ is significantly different from 1.0 and the $y$ intercept $(+14 \pm 6 \%$ ) is significantly different from 0 . Additionally, we find a significant correlation $(r=0.80, p=0.05)$ between surface $\Delta^{14} \mathrm{C}$ vs. $20-25$ $\mathrm{m} \Delta{ }^{14} \mathrm{C}$ for 2 other sites: the mid-North Pacific Ocean occupied in November 1985, June 1987, and June 1999, and the Sargasso Sea occupied in July 1989 and June 2000 (Druffel and Griffin 2008) (dotted line, Figure 4). The slope of the least-squares fit $(0.647 \pm 0.140)$ is significantly different from 1.0 and the $y$ intercept is $+54 \pm 16 \%$, indicating that most of the $\Delta{ }^{14} \mathrm{C}$ values at these 2 surface locations were higher than those deeper in the mixed layer.

Bomb ${ }^{14} \mathrm{C}$ levels were highest in the subtropical surface ocean during the $1970 \mathrm{~s}$, and declined subsequently along with atmospheric levels as the ${ }^{14} \mathrm{C}$ spike penetrated deeper into the ocean's interior. By the $1990 \mathrm{~s}, \Delta^{14} \mathrm{C}$ values were higher at depth down to $250 \mathrm{~m}$ than in the surface waters of the northeastern Pacific (Key et al. 1996). This trend does not appear at Stn M, because $\Delta^{14} \mathrm{C}$ values at 1,25 , and $80 \mathrm{~m}$ depth are similar (Masiello et al. 1998). At Stn M, there is stronger mixing between surface and subsurface layers, associated with upwelling and the southward-flowing California Current.

Additionally, the influence of upwelling in the eastern Pacific is demonstrated using a plot of surface ocean DIC $\Delta{ }^{14} \mathrm{C}$ during the last 2 decades (Figure 5). Included are cruise-averaged $\Delta^{14} \mathrm{C}$ values from Stn $\mathrm{M}$ and the north central Pacific (Druffel and Griffin 2008), seasonal coral bands from Kikai Island, southern Japan (Morimoto et al. 2004), and atmospheric $\mathrm{CO}_{2}$ in Schauinsland, Germany (Levin and Kromer 2004). It is clear that surface ocean $\Delta^{14} \mathrm{C}$ in the central and western Pacific had reached similar values as those in the atmosphere by the late 1990 s. In contrast, $\Delta^{14} \mathrm{C}$ values in the eastern Pacific (Stn M) remained well below those in the atmosphere, by about 30-40\%, presumably maintained by a steady supply of low- ${ }^{14} \mathrm{C}$ waters from subsurface levels, i.e. upwelling. 


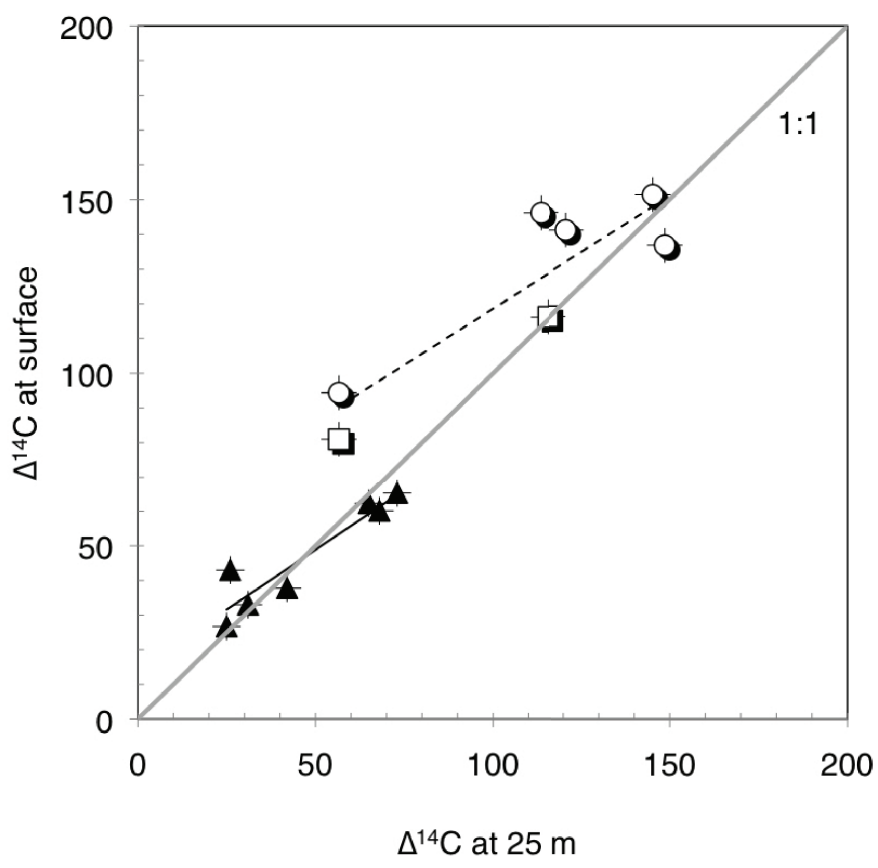

Figure 4 DIC $\Delta^{14} \mathrm{C}$ measurements of surface water $\left(y\right.$ axis) versus DIC $\Delta^{14} \mathrm{C}$ measurements from $25 \mathrm{~m}$ depth ( $x$ axis) collected on the same day. Filled triangles are from Pulse cruises (this work) to Station $\mathrm{M}$ and the black line is the least-squares fit of these data. Other points are for 2 open ocean sites reported previously (Druffel and Griffin 2008): the north central Pacific (1985, 1987 and 1999, circles), and the Sargasso Sea (1989 and 2000, squares) and the dashed line is the least-squares fit of these data.

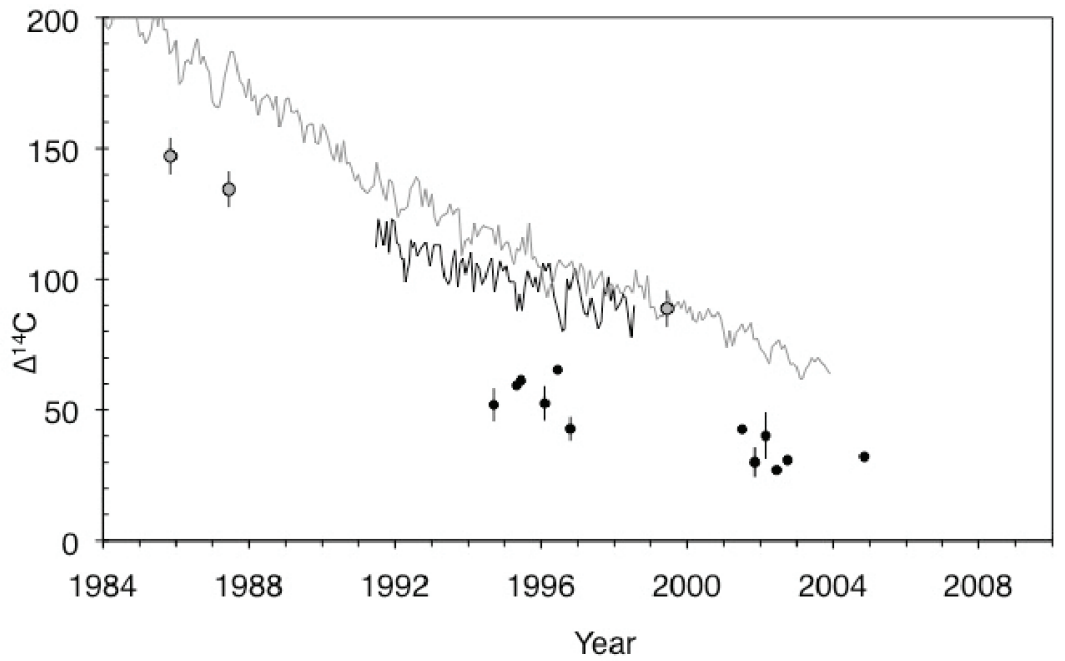

Figure 5 Surface $\Delta^{14} \mathrm{C}$ measurements of DIC at Stn M (black circles, this work) and north central Pacific (gray circles, Druffel and Griffin 2008), seasonal coral bands from Kikai Island, southern Japan (black line, Morimoto et al. 2004) and atmospheric $\mathrm{CO}_{2}$ in Schauinsland, Germany (gray line, Levin and Kromer 2004). 


\section{CONCLUSIONS}

In general, $\Delta^{14} \mathrm{C}$ values decreased at a rate of about 3\%o per year between 1994 and 2004, about half of that in atmospheric $\mathrm{CO}_{2}$ during the same period (Levin and Kromer 2004). We observed that daily $\Delta^{14} \mathrm{C}$ values of surface DIC during 12 cruises ranged from $2-18 \%$. Variability of average cruise $\Delta^{14} \mathrm{C}$ values is highest during winter likely due to increased mixing. This indicates that a single $\Delta^{14} \mathrm{C}$ measurement from a surface site is not sufficient to capture the true variability of $\Delta^{14} \mathrm{C}$ in the surface ocean. We recommend that several samples be collected over several days from near-surface depths, whenever possible.

\section{ACKNOWLEDGMENTS}

Thanks to Carrie Masiello, Bob Wilson, Bridget Griffin Lanflisi, and Ai Ning Loh for help with sample collection; Kevin Druffel-Rodriguez for graphite preparation; John Southon and Guaciara dos Santos (Keck Carbon Cycle AMS Lab), Tom Guilderson (LLNL CAMS), and Ann McNichol (NOSAMS) for help with AMS measurements; Catherine Goyet, Becky Belastock, and Dan McCorkle for the alkalinity and $\mathrm{TCO}_{2}$ measurements; and the ODF group (Scripps) for the salinity measurements. We thank Ken Smith for generously sharing his ship time, the resident technicians and crew of the R/V New Horizon for assistance aboard ship, and Charlene Grall (University of Miami Tritium Lab) and Sandy O'Brien (Scripps) for swabs of the ship. We are grateful to 2 anonymous reviewers for their helpful comments on the manuscript. The W M Keck Foundation and NSF Chemical Oceanography Program (OCE-9815130 and OCE-0551940) provided funding for this research.

\section{REFERENCES}

Beaupré S, Druffel E. 2009. Constraining the propagation of bomb-radiocarbon through the dissolved organic carbon (DOC) pool in the northeast Pacific Ocean. Deep-Sea Research I 56(10):1717-26.

Bradshaw AL, Brewer PG, Shafer DK, Williams RT. 1981. Measurements of total carbon dioxide and alkalinity by potentiometric titration in the GEOSECS program. Earth and Planetary Science Letters 55(1): 99-115.

Brewer P, Bradshaw A, Williams R. 1986. Measurements of total carbon dioxide and alkalinity in the North Atlantic Ocean in 1981. In: Trabalka JR, Reichle D, editors. The Changing Carbon Cycle: A Global Analysis. New York: Springer-Verlag. p 358-81.

Brown T, Farwell G, Grootes P, Schimidt F, Stuiver M. 1993. Intra-annual variability of the radiocarbon content of corals from the Galapagos Islands. Radiocarbon 35(2):245-51.

DOE. 1994. Handbook of Method for the Analysis of the Various Parameters of the Carbon Dioxide System in Seawater. Version 2. Dickson AG, Goyet C, editors. ORNL/CDIAC-74.

Druffel E, Griffin S. 2008. Daily variability of dissolved inorganic radiocarbon at three sites in the surface ocean. Marine Chemistry 110(3-4):185-9.

Guilderson T, Schrag DP, Goddard E, Kashgarian M, Wellington GM, Linsley BK. 2000. Southwest subtropical Pacific surface water radiocarbon in a highresolution coral record. Radiocarbon 42(2):249-56.

Key RM, Quay PD, Jones GA, McNichol AP, von Reden KF, Schneider RJ. 1996. WOCE AMS radiocarbon I:

Pacific Ocean results (P6, P16 and P17). Radiocarbon 38(3):425-518.

Levin I, Kromer B. 2004. The tropospheric ${ }^{14} \mathrm{CO}_{2}$ level in mid-latitudes of the Northern Hemisphere (19592003). Radiocarbon 46(3):1261-72.

Masiello C, Druffel E, Bauer J. 1998. Physical influences on dissolved inorganic radiocarbon variability in the California Current. Deep-Sea Research II 45(4-5): 617-42.

McDuffee K, Druffel E. 2007. Daily variability of dissolved inorganic radiocarbon in Sargasso Sea surface waters. Marine Chemistry 106(3-4):510-5.

McNichol AP, Jones G, Hutton D, Gagnon A. 1994. The rapid preparation of seawater $\Sigma \mathrm{CO}_{2}$ for radiocarbon analysis at the National Ocean Sciences AMS Facility. Radiocarbon 36(2):237-46.

Morimoto M, Kitagawa H, Shibata Y, Kayane H. 2004. Seasonal radiocarbon variation of surface seawater recorded in a coral from Kikai Island, subtropical northwestern Pacific. Radiocarbon 46(2):643-8.

Southon J, Santos G, Druffel-Rodriguez K, Druffel E, Trumbore S, Xu X, Griffin S, Ali S, Mazon M. 2004. The Keck Carbon Cycle AMS Laboratory, University of California, Irvine: initial operation and a background surprise. Radiocarbon 46(1):41-50.

Stuiver M, Polach HA. 1977. Discussion: reporting of ${ }^{14} \mathrm{C}$ data. Radiocarbon 19(3):355-63.

Wolter K. 2007. Multivariate ENSO Index (MEI) [WWW document]. URL: http://www.esrl.noaa.gov/ psd/people/klaus.wolter/MEI/. 